\title{
Poly(ADP-Ribose) Polymerase-1 Mediates Angiotensin II-Induced Expression of Plasminogen Activator Inhibitor-1 and Fibronectin in Rat Mesangial Cells
}

\author{
Hengmei Zhu Zongpei Jiang Ping Lei Wen Huang Xueqing Yu \\ Department of Nephrology, The First Affiliated Hospital, Sun Yat-sen University, Guangzhou, China
}

\section{Key Words}

Rat mesangial cells $\cdot$ Angiotensin II $\cdot$ Poly(ADP-ribose)

polymerase-1 1 Plasminogen activator inhibitor-1 •

Fibronectin

\begin{abstract}
Objective: To investigate the effects of poly(ADP-ribose) polymerase-1 (PARP-1) on angiotensin II (Ang II)-induced plasminogen activator inhibitor-1 (PAI-1) and fibronectin (FN) in rat mesangial cells (RMCs). Methods: Followed by serum starvation for $16 \mathrm{~h}$, RMCs were exposed to Ang II for an indicated time to examine the protein expression of PARP-1. The cells were treated with or without Ang II for $12-24 \mathrm{~h}$ in the presence or absence of an inhibitor of PARP, N-(6-oxo5,6-dihydrophenanthridin-2-yl)-N,N-dimethylacetamide hydrochloride (PJ34) or small interfering RNA (siRNA) duplexes targeting PARP-1. The mRNA and protein expressions of PARP-1, PAI-1 and FN were determined by real-time RT-PCR and Western blot, respectively. The activity of PARP-1 was examined by colorimetric assay. Results: Ang II did not only significantly induce PARP-1 expression and activity, but also increased PAI-1 and FN expression in RMCs. All these responses induced by Ang II were significantly inhibited by both the PARP inhibitor PJ34 and downregulating PARP-1 with the siRNA technique. Conclusions: Our data suggest
\end{abstract}

\section{KARGER}

Fax +41613061234 E-Mail karger@karger.ch www.karger.com

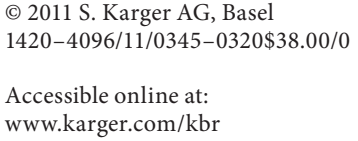

that PARP-1 mediates Ang II-induced PAI-1 and FN in RMCs and may thus represent a potential therapeutic target in the treatment of glomerular disease.

Copyright $\odot 2011$ S. Karger AG, Basel

\section{Introduction}

Chronic kidney disease (CKD) is common in China and worldwide $[1,2]$. The estimated prevalence of CKD in south Chinese adults was more than $12.0 \%$ in 2007 , based on the survey conducted by our hospital [3]. CKD is now recognized as an independent risk factor for both end-stage renal disease and cardiovascular disease [4]. Representative remodeling of the kidney in CKD includes development of glomerulosclerosis and tubulointerstitial fibrosis $[5,6]$. Activation of the renin-angiotensin system, which increases the synthesis of angiotensin II (Ang II), is a common manifestation in patients with CKD. In CKD patients, systemic and internal renal concentration of renin and Ang II is frequently inappropriately high, and the latter is even much higher and plays more prominent roles in the pathogenesis of glomerulo-

\section{H. Zhu and Z. Jiang contributed equally to this work.}


sclerosis and tubulointerstitial fibrosis, as well as many cardiovascular disorders [5]. Ang II is not only a vasoactive agent that participates in local and systemic hemodynamic regulation, but also acts as a potent cytokine that regulates cell growth, epithelial-mesothelial transition and extracellular matrix (ECM) synthesis and degradation $[7,8]$. Plasminogen activator inhibitor-1 (PAI-1) is a key regulator in ECM remodeling and renal fibrosis. Increasing evidence has proven that PAI-1 takes part in the Ang II signaling pathway [9-12]. TGF- $\beta$ and several other factors were also reported to participate in those processes involved in Ang II [9-12], but in vivo and in vitro research shows weak amelioration of renal diseases using inhibitors of those factors. It pushes us to explore some new mediators, which may play important roles in Ang II-induced renal diseases.

Poly(ADP-ribose) polymerase (PARPs), the second most abundant non-histone nuclear protein, is a series of poly(ADP-ribosyl)ation enzymes present in eukaryotes $[13,14]$. PARP-1 is the most abundant and important enzyme among the family, which consists of almost $80 \%$ portion and accounts for about $90 \%$ of total cellular PARP activity [15]. When DNA is damaged, it senses and binds to DNA nick, forms homodimers and catalyzes the cleavage of nicotinamide dinucleotide (oxidized) (NAD+) into nicotinamide and ADP-ribose and uses the latter to synthesize branched nucleic acid-like polymers poly (ADP-ribose) covalently attached to nuclear acceptor proteins, in particular histones, several transcription factors like NF- $\kappa \mathrm{B}$, and PARP itself, thereby regulating their activities and functions [13-15]. A hypothesis regarding PARP says that PARP is critical for many physiological events like cellular differentiation and proliferation, genome integrity, cell survival and cell death when properly activated, but causing many pathophysiological outcomes, such as inflammation, carcinogenesis and neuronal functions when improperly activated [16]. Some reports observed the overactivation of PARP-1 in diabetic complications. Du et al. [17] detected PARP-1 activation and abnormal accumulation of glucose metabolic product in aorta endothelial cells stimulated by high glucose. Szabo et al. [18] discovered in $\mathrm{db} / \mathrm{db}$ diabetic mice that the activity of PARP-1 increased in the kidney, and its specific inhibitor dramatically attenuated proteinuria, glomerular mesangium expansion and podocyte injury. Furthermore, PARP-1 inhibitors ameliorate nephropathy of type 2 diabetic Leprdb/db mice [19]. A recent study reported that PARP-1 gene deficiency alleviated diabetic kidney disease through decreasing mesangial expansion and fibronectin (FN) expression [20]. In addition, inhibi- tion of PAPR-1 by its inhibitor, PJ34, diminished PAI-1 and attenuated ventilator-induced lung injury [21]. These studies suggest that PAI-1 and FN are downstream of PARP-1. Therefore, we hypothesize that PARP-1 may act as a potential mediator in Ang II-induced CKD. In this study, we aim to examine whether PARP-1 regulates expression of PAI-1 and FN in Ang II-induced rat mesangial cells (RMCs).

\section{Methods}

Chemicals and Reagents

Ang II was purchased from Sigma-Aldrich (St. Louis, Mo., USA). Trypsin, ethylenediamine tetraacetic acid, fetal bovine serum, RPMI 1640 medium and TRIzol ${ }^{\mathrm{TM}}$ reagent were purchased from Invitrogen (Carlsbad, Calif., USA). Insulin was from Gan \& Lee Pharmaceutical Ltd (Beijing, China). PJ34 was from Calbiochem. Cell lysis, mouse anti-rat $\beta$-actin monoclonal antibody, horseradish peroxidase-labeled secondary antibody against mouse or rabbit were purchased from Cell Signaling Technology. Rabbit anti-PARP polyclonal antibody and rabbit anti-mouse PAI-1 polyclonal antibody were purchased from Santa Cruz. The RevertAid $^{\mathrm{TM}}$ First Strand cDNA reverse transcription kit was purchased from Fermentas and the HT colorimetric PARP/apoptosis assay was purchased from Trevigen Inc. (Gaithersburg, Md., USA).

\section{Cell Culture}

A rat mesangial cell line (MCs 1097), obtained from ATCC, was cultured in RPMI 1640 medium containing 15\% fetal bovine serum and $0.6 \mathrm{U} / \mathrm{ml}$ insulin. Subconfluent mesangial cells were incubated with serum-free medium for $16 \mathrm{~h}$ to arrest and synchronize the cell growth. The cells were treated with fresh serumfree RPMI 1640 medium containing Ang II $\left(10^{-7} \mathrm{M}\right)$. Cells were pretreated with the PARP-1 inhibitor PJ34 $\left(3 \times 10^{-6} \mathrm{M}\right)$ for $1 \mathrm{~h}$ followed by Ang II stimulation for 12 and $24 \mathrm{~h}$, and cells were harvested at $12 \mathrm{~h}$ to collect total RNA and at $24 \mathrm{~h}$ to collect total protein for further analysis. Total RNA from RMCs was extracted using TRIzol reagent according to the manufacturer's instructions. Total protein was extracted using the method described by Rhyu et al. [22]. At the end of incubation, the cells were washed with PBS and lysed in $80 \mu \mathrm{l}$ of lysis buffer containing protease inhibitors for $5 \mathrm{~min}$ on ice. Conditioned medium and cell lysates were centrifuged at $13,000 \mathrm{~g}$ at $4^{\circ} \mathrm{C}$ for $10 \mathrm{~min}$, and the concentration of cellular protein was determined by the Pierce BCA assay.

\section{siRNA Transfection}

Small interfering RNAs (siRNAs) were designed and synthesized by Genepharma Inc. (Shanghai, China). Sequences of PARP-1 siRNA duplexes were sense 5'-GGGCAAGCACAGUGUCAAATT- $3^{\prime}$ and antisense $5^{\prime}$-UUUGACACUGUGCUUGCCCTT-3'. siRNA duplexes were transfected into cells (50-70\% confluence) using Lipofectamine 2000 siRNA transfection reagent (Invitrogen). Briefly, $4 \mu \mathrm{l}$ Lipofectamine 2000 and $1.5 \mu \mathrm{l}$ PARP-1 siRNA duplexes $\left(5 \times 10^{-8} \mathrm{M}\right)$ were first diluted into 300 $\mu l$ optimal medium, respectively, without serum and antibiotics, 
Table 1. Primer sequences and reaction conditions used for RT-PCR

\begin{tabular}{|c|c|c|c|}
\hline Gene & Primer sequences & Size, bp & Reaction condition \\
\hline PARP-1 & $\begin{array}{l}\text { forward: } 5^{\prime} \text {-ACGCACAATGCCTATGAC-3' } \\
\text { reverse: } 5^{\prime} \text {-CACATCTCCAAGGCGACC-3' }\end{array}$ & 441 & $\begin{array}{l}94^{\circ} \mathrm{C} 5 \mathrm{~min}, 94^{\circ} \mathrm{C} 30 \mathrm{~s}, 58^{\circ} \mathrm{C} 30 \mathrm{~s}, \\
72^{\circ} \mathrm{C} 45 \mathrm{~s}, 29 \text { cycles, } 72^{\circ} \mathrm{C} 10 \mathrm{~min}\end{array}$ \\
\hline PAI-1 & $\begin{array}{l}\text { forward: } \text { 5'-ATGGAACAAGAATGAGATCA-3' }^{\prime} \\
\text { reverse: } \\
\text { 5'-TCA AAGGGTGCTGCAATGAAC-3' }\end{array}$ & 471 & $\begin{array}{l}94^{\circ} \mathrm{C} 5 \mathrm{~min}, 94^{\circ} \mathrm{C} 30 \mathrm{~s}, 53^{\circ} \mathrm{C} 30 \mathrm{~s}, \\
72^{\circ} \mathrm{C} 45 \mathrm{~s}, 32 \text { cycles, } 72^{\circ} \mathrm{C} 10 \mathrm{~min}\end{array}$ \\
\hline FN & $\begin{array}{l}\text { forward: } 5^{\prime} \text {-CTGAAGTCACTTCTCGGGGTGC-3' } \\
\text { reverse: } 5^{\prime} \text {-GCACAACAGACCACCAAACTCG-3' }\end{array}$ & 430 & $\begin{array}{l}94^{\circ} \mathrm{C} 5 \mathrm{~min}, 94^{\circ} \mathrm{C} 30 \mathrm{~s}, 56^{\circ} \mathrm{C} 30 \mathrm{~s}, \\
72^{\circ} \mathrm{C} 45 \mathrm{~s}, 29 \text { cycles, } 72^{\circ} \mathrm{C} 10 \mathrm{~min}\end{array}$ \\
\hline$\beta$-Actin & $\begin{array}{l}\text { forward: } 5^{\prime} \text {-GGGAAATCGTGCGTGACATTA-3' } \\
\text { reverse: } 5^{\prime} \text {-TCGTCATACTCCTGCTTGCTG-3' }\end{array}$ & 475 & $\begin{array}{l}94^{\circ} \mathrm{C} 5 \mathrm{~min}, 94^{\circ} \mathrm{C} 30 \mathrm{~s}, 53^{\circ} \mathrm{C} 30 \mathrm{~s}, \\
72^{\circ} \mathrm{C} 45 \mathrm{~s}, 28 \text { cycles, } 72^{\circ} \mathrm{C} 10 \mathrm{~min}\end{array}$ \\
\hline
\end{tabular}

Table 2. Primer sequences for real-time PCR

\begin{tabular}{|c|c|c|}
\hline Gene & Primer sequences & Size, bp \\
\hline PARP-1 & $\begin{array}{ll}\text { forward: } & \text { 5'-ACACGTTAGCGGAGCGGACCG-3' } \\
\text { reverse: } & \text { 5'-CGCCCGCTCTTAGCGTACTCC-3' }\end{array}$ & 113 \\
\hline PAI-1 & $\begin{array}{ll}\text { forward: } & \text { 5'-ACCTGGGTCAGTCGAAGCGGA-3' } \\
\text { reverse: } & 5^{\prime} \text {-CGCATTGGCCCGTGCTGGTA-3' }\end{array}$ & 153 \\
\hline $\mathrm{FN}$ & $\begin{array}{ll}\text { forward: } & 5^{\prime} \text {-TCAGCCATGTCCAATCCC-3' } \\
\text { reverse: } & 5^{\prime} \text {-CATACCCGTAGCATCCACC-3' }\end{array}$ & 135 \\
\hline$\beta$-Actin & $\begin{array}{ll}\text { forward: } & 5^{\prime} \text {-ACAACCTTCTTGCAGCTCCTCCG-3' } \\
\text { reverse: } & 5^{\prime} \text {-GTTGTCGACGACGAGCGCAGC-3' }\end{array}$ & 89 \\
\hline
\end{tabular}

mixed gently and incubated for $5 \mathrm{~min}$ at room temperature and then the two mixed gently and incubated for $30 \mathrm{~min}$ and added to the new mixture into cells. Negative control cells were treated with negative control vectors consisting of a scrambled siRNA. The cells were incubated for $6 \mathrm{~h}$ and the medium changed with RPMI 1640 containing 15\% FBS overnight. The transfected mesangial cells were then incubated with serum-free media for $16 \mathrm{~h}$ to arrest and synchronize the cell growth. The cells were treated with fresh serum-free RPMI 1640 medium containing Ang II $\left(10^{-7} \mathrm{M}\right)$.

\section{Reverse Transcription Polymerase Chain Reaction}

The mRNA levels of PARP-1, PAI-1 and FN were assessed by reverse transcription polymerase chain reaction (RT-PCR). One microgram total RNA was reverse transcribed into $\mathrm{CDNA}$ with the Fermentas RevertAid First Strand cDNA synthesis system according to the manufacturer's instructions. Subsequently, the polymerase reaction was performed using the TaKaRa system. The forward and reverse primers and reaction condition used in this study are shown in table 1 . Each sample was performed in triplicate. To confirm the amplification specification, the PCR products were subject to a melting-curve analysis and subsequent agarose gel electrophoresis. The result was normalized by $\beta$-actin and expressed as relative changes to control.

\section{Quantitative Real-Time PCR}

The total RNA was extracted from RMCs using TRIzol reagent according to the manufacturer's instructions. Total RNA $(1 \mu \mathrm{g})$ was reverse transcribed, followed by quantitative real-time PCR using the Bio-Rad iCycler Iq system. The PCR reactions were carried out in a total volume of $25 \mu$ l containing $12.5 \mu \mathrm{l}$ of SYBR Premix Ex Taq ${ }^{\mathrm{TM}}(2 \times)$ (TaKaRa Biotechnology Co., Ltd, Dalian, China), $2 \mu$ l of cDNA, 5 pmol of forward and reverse primers, and $9.5 \mu \mathrm{l}$ of distilled $\mathrm{H}_{2} \mathrm{O}$. The sequences of the primers used are listed in table 2. PCR was performed at $95^{\circ} \mathrm{C}$ for $30 \mathrm{~s}$, and then run for $45 \mathrm{cycles}$ at $95^{\circ} \mathrm{C}$ for $5 \mathrm{~s}$ and $60^{\circ} \mathrm{C}$ for $20 \mathrm{~s}$. The relative amount of mRNA was calculated using the comparative $C_{\mathrm{t}}\left(\Delta \Delta C_{\mathrm{t}}\right)$ [23]. The derived normalized values were the mean of three runs.

\section{Western Blot Analysis}

The protein levels of PARP-1, FN and PAI-1 protein expression were examined by the Western blot method. Samples with equal concentrations of cellular protein $(20 \mu \mathrm{g})$ were mixed with a $2 \times$ sample buffer and was heated at $95^{\circ} \mathrm{C}$ for 5 min and separated on $8 \%$ SDS-polyacrylamide gels. After electrophoresis for $90 \mathrm{~min}$, the proteins were transferred onto a nitrocellulose membrane using a transblot chamber with Tris buffer $(0.025 \mathrm{M}$ Tris- $\mathrm{HCl}$, $0.192 \mathrm{M}$ glycine, and $20 \% \mathrm{MeOH})$. The membrane was blocked for $1 \mathrm{~h}$ at room temperature with 5\% non-fat milk in $0.1 \%$ TBS-Tween 
Table 3. Effect of PJ34 and siRNA duplexes targeting PARP-1 on Ang II-induced PARP-1 activation in RMCs determined by colorimetric assay

\begin{tabular}{ll}
\hline Group & PARP-1 activity, U/mg protein \\
\hline 1 & $0.033989 \pm 0.005841$ \\
2 & $0.052223 \pm 0.008282^{\mathrm{a}}$ \\
3 & $0.033701 \pm 0.005180^{\mathrm{b}}$ \\
4 & $0.032065 \pm 0.005224^{\mathrm{c}}$ \\
\hline
\end{tabular}

PARP-1 activity in RMCs determined by colorimetric assay: $1=$ RMC treated with vehicle (blank), $2=\mathrm{RMC}$ treated with Ang II $(0.1 \mu \mathrm{M}), 3=\mathrm{RMC}$ pretreated with PJ34 $(3 \mu \mathrm{M})$ followed by Ang II $(0.1 \mu \mathrm{M})$ treatment, $4=\mathrm{RMC}$ pretreated with PARP-1 siRNA (50 nM) followed by Ang II $(0.1 \mu \mathrm{M})$ treatment.

Data are expressed as mean \pm SD from three independent experiments.

${ }^{\mathrm{a}} \mathrm{p}<0.05$ (2 vs. 1$)$; ${ }^{\mathrm{b}} \mathrm{p}<0.05$ (3 vs. 2 ); ${ }^{\mathrm{c}} \mathrm{p}<0.05$ (4 vs. 2 ).

20. The membranes were incubated at $4^{\circ} \mathrm{C}$ overnight with a dilution of antibody of PARP-1, FN and PAI-1. After extensive washing in TBS-Tween 20, the membranes were then incubated with secondary anti-mouse IgG or anti-rabbit IgG for $1 \mathrm{~h}$ at room temperature. After washing, the membranes were incubated with an enhanced chemiluminescence system detection kit. Positive immunoreactive bands were quantified densitometrically, normalized by $\beta$-actin and compared with controls.

\section{PARP Activity Assay}

PARP activity was assayed using the universal colorimetric PARP assay kit (Trevigen Inc., USA), based on the incorporation of biotinylated ADP-ribose onto histone proteins. Cell lysates from RMCs containing about $50 \mu \mathrm{g}$ of protein were loaded into a 96-well plate coated with histones and biotinylated poly-ADP-ribose, allowed to incubate for $1 \mathrm{~h}$, treated with streptavidin-horseradish peroxidase, and read at $450 \mathrm{~nm}$ in a spectrophotometer.

\section{Statistical Analysis}

All results are expressed as mean \pm SD with $n$ as the number of experiments. Analysis of variance (ANOVA) was used to assess the differences between multiple groups using SPSS 13.0 software (SPSS Inc., Chicago, Ill., USA). A value of $\mathrm{p}<0.05$ was considered statistically significant.

\section{Results}

\section{Effects of Ang II on PARP-1 Protein Expression in} RMCs

Figure 1 shows Ang II-induced PARP-1 expression from 12 to $48 \mathrm{~h}$. The PARP-1 protein expression of the Ang II group at $12,24,36$, or $48 \mathrm{~h}$ was upregulated by 158.6, 226.5, 244.9, and 180.1\% ( $<<0.05)$, compared with

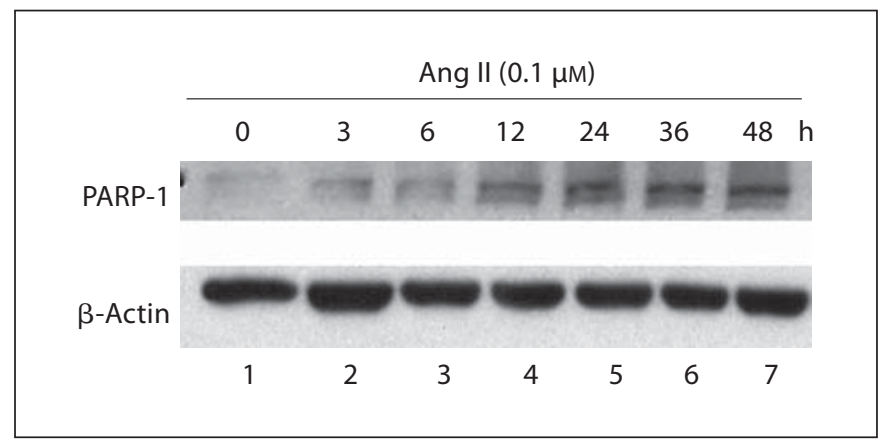

Fig. 1. Effects of Ang II on PARP-1 protein expression in RMCs determined by Western blot: RMCs were exposed to Ang II (0.1 $\mu \mathrm{M}$ ) for (1) $0 \mathrm{~h}$, (2) $3 \mathrm{~h}$, (3) $6 \mathrm{~h}$, (4) $12 \mathrm{~h}$, (5) $24 \mathrm{~h}$, (6) $36 \mathrm{~h}$, and (7) $48 \mathrm{~h}$.

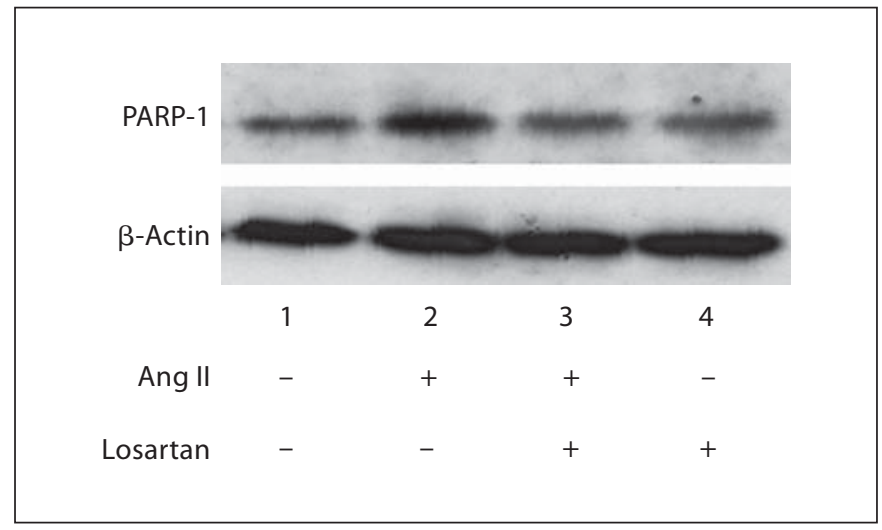

Fig. 2. Effect of losartan on Ang II-induced PARP-1 expression in RMCs by Western blot: (1) RMCs treated with vehicle (blank), (2) RMCs treated with Ang II (0.1 $\mu \mathrm{M})$, (3) RMCs pretreated with losartan $(10 \mu \mathrm{M})$ followed by Ang II $(0.1 \mu \mathrm{M})$ treatment, and (4) RMCs treated with losartan $(10 \mu \mathrm{M})$ alone.

control cells, respectively $(\mathrm{p}<0.05)$. Therefore, we chose the optimal time to examine effects of PJ34 and siRNA duplex targeting PARP-1 on Ang II-induced PARP-1 activity and expression at $24 \mathrm{~h}$.

\section{Effect of PJ34 and siRNA Duplex Targeting PARP-1}

on Ang II-Induced PARP-1 Activity in RMCs

As shown in table 3 , Ang II obviously stimulated PARP- 1 activity at $24 \mathrm{~h}$. In addition, the PARP- 1 activity of the Ang II group was upregulated by $53.6 \%(\mathrm{p}<0.05)$, compared with control cells. PJ34 and PARP-1 siRNA duplex both effectively inhibited the activation of PARP-1 by 35.5 and $38.6 \%$, respectively ( $p<0.05$ ), when compared with the cells treated with Ang II alone. 


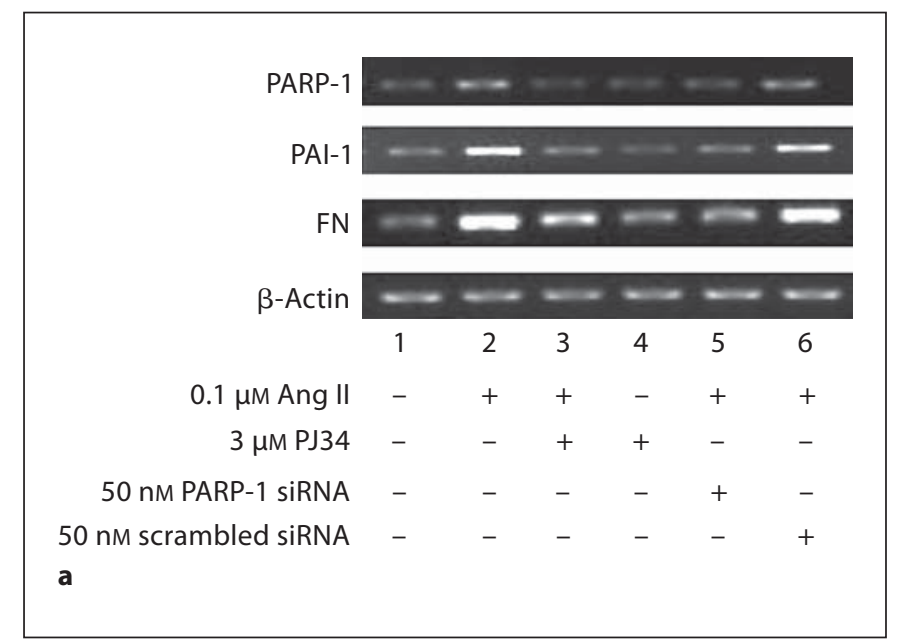

Fig. 3. Effects of PJ34 and siRNA duplexes targeting PARP-1 on Ang II-induced PARP-1, PAI-1 and FN mRNA in RMCs at $12 \mathrm{~h}$ determined by RT-PCR (a) and real-time PCR (b), respectively. The intensity of the resultant bands are scanned and expressed as a ratio of $\beta$-actin: (1) RMCs treated with vehicle (blank), (2) RMCs treated with Ang II $(0.1 \mu \mathrm{M})$, (3) RMCs pretreated with PJ34

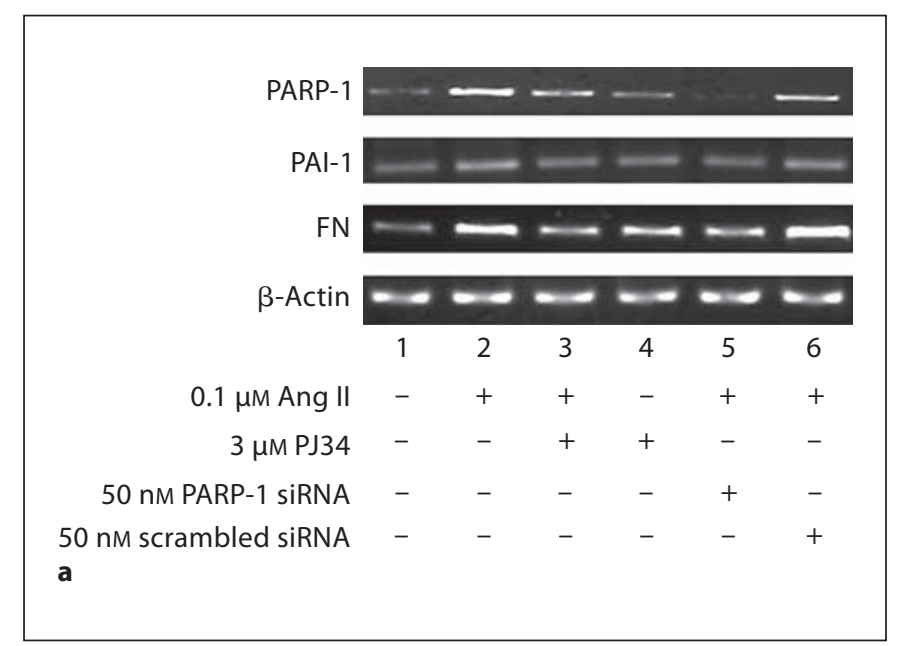

Fig. 4. Effects of PJ34 and siRNA duplexes targeting PARP-1 on Ang II-induced PARP-1, PAI- 1 and FN mRNA in RMCs at $24 \mathrm{~h}$ determined by RT-PCR (a) and real-time PCR (b), respectively. The intensity of the resultant bands are scanned and expressed as a ratio of $\beta$-actin: (1) RMCs treated with vehicle (blank), (2) RMCs treated with Ang II (0.1 $\mu \mathrm{M})$, (3) RMCs pretreated with PJ34

\section{Effect of Angiotensin Receptor in Ang II-Induced PARP-1 in RMCs}

The effect of angiotensin receptor blockade on Ang IIinduced PARP-1 in RMCs has not been elucidated. As shown in figure 2, Ang II-induced PARP-1 in RMCs was

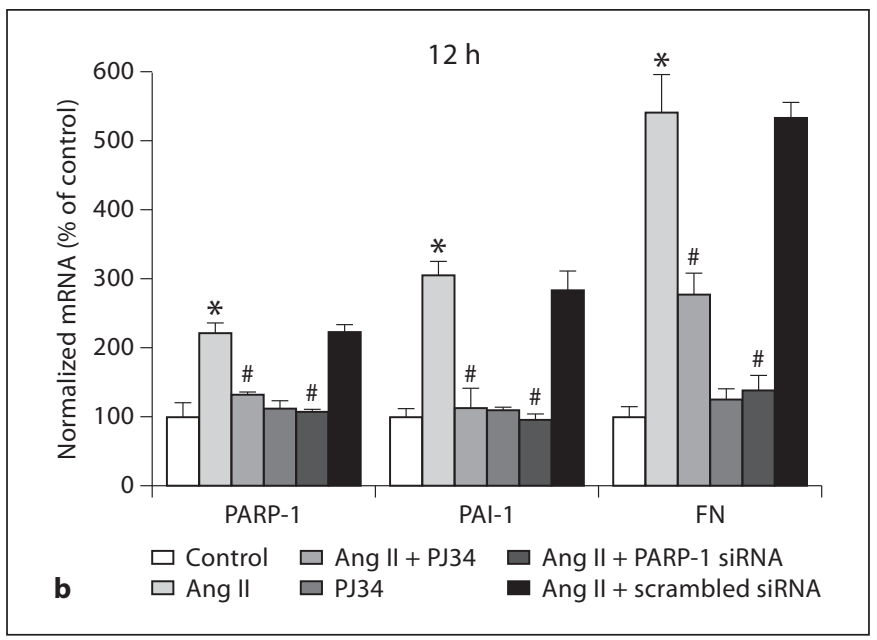

(3 $\mu \mathrm{M})$ followed by Ang II $(0.1 \mu \mathrm{M})$ treatment, (4) RMCs treated with PJ34 (3 $\mu \mathrm{M})$ alone, (5) RMCs pretreated with PARP-1 siRNA (50 nM) followed by Ang II (0.1 $\mu \mathrm{M})$ treatment, and (6) RMCs treated with scrambled siRNA $(50 \mathrm{nM})$ followed by Ang II (0.1 $\mu \mathrm{M})$. Data are expressed as mean $\pm \mathrm{SD}(\mathrm{n}=3) .{ }^{*} \mathrm{p}<0.01$ versus control; ${ }^{*} \mathrm{p}<0.01$ versus Ang II alone.

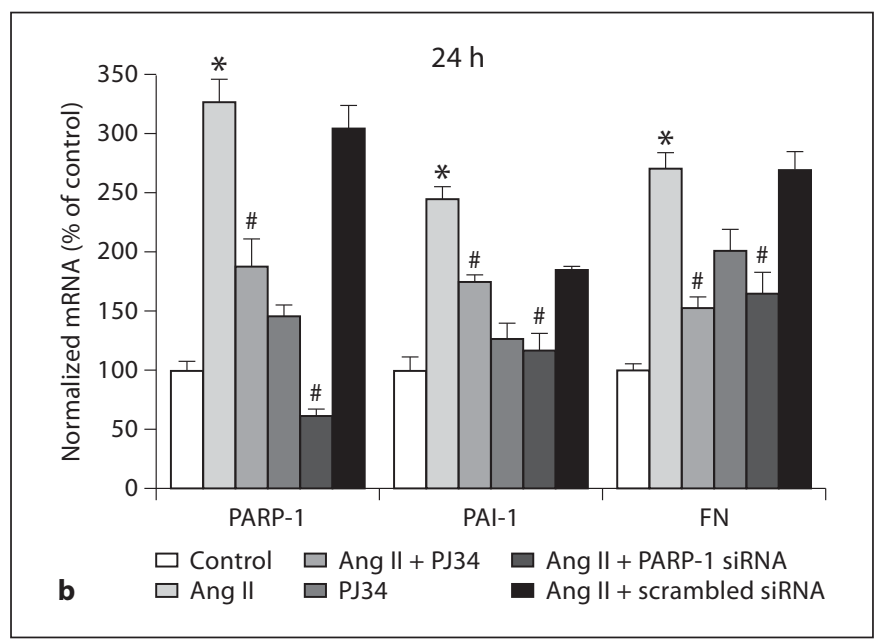

(3 $\mu \mathrm{M})$ followed by Ang II $(0.1 \mu \mathrm{M})$ treatment, (4) RMCs treated with PJ34 (3 $\mu \mathrm{M})$ alone, (5) RMCs pretreated with PARP-1 siRNA (50 nM) followed by Ang II (0.1 $\mu \mathrm{M})$ treatment, and (6) RMCs treated with scrambled siRNA $(50 \mathrm{nM})$ followed by Ang II (0.1 $\mu M)$. Data are expressed as mean $\pm S D(n=3) .{ }^{*} p<0.01$ versus control; ${ }^{\#} \mathrm{p}<0.01$ versus Ang II alone. 


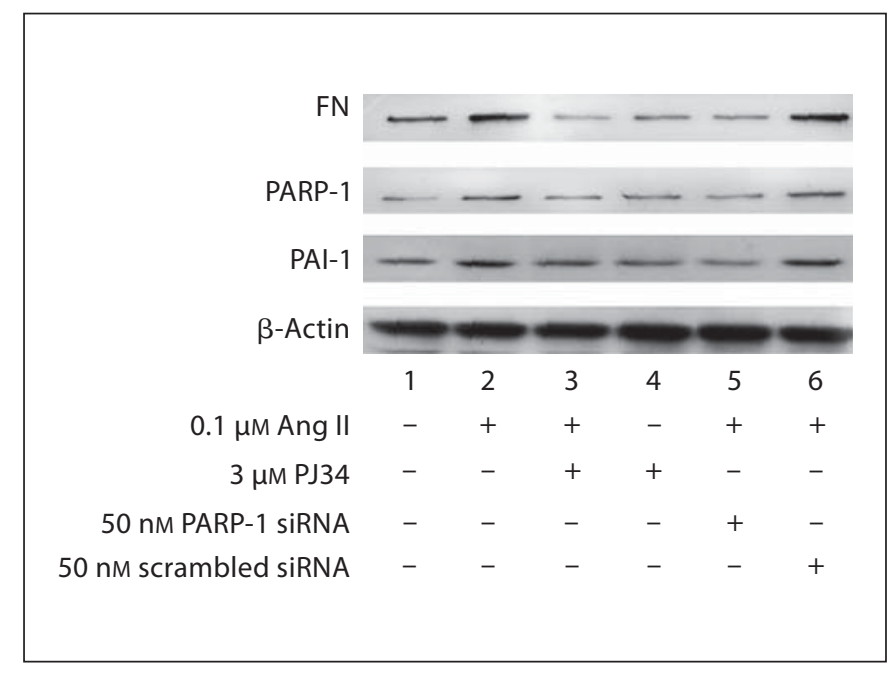

Fig. 5. Effects of PJ34 and siRNA duplexes targeting PARP-1 on Ang II-induced protein expression of PARP-1, PAI-1 and FN in RMCs at $12 \mathrm{~h}$ determined by Western blot. The intensity of the resultant bands are scanned and expressed as a ratio of $\beta$-actin: (1) RMCs treated with vehicle (blank), (2) RMCs treated with Ang II $(0.1 \mu \mathrm{M}),(3) \mathrm{RMCs}$ pretreated with PJ34 (3 $\mu \mathrm{M})$ followed by Ang II $(0.1 \mu \mathrm{M})$ treatment, (4) RMCs treated with PJ34 (3 $\mu \mathrm{M})$ alone, (5) RMCs pretreated with PARP-1 siRNA (50 nM) followed by Ang II $(0.1 \mu \mathrm{M})$ treatment, and (6) RMCs treated with scrambled siRNA $(50 \mathrm{nM})$ followed by Ang II $(0.1 \mu \mathrm{M})$.

\section{Effect of PJ34 and siRNA Duplex Targeting PARP-1} on Ang II-Induced mRNA of PARP-1, FN and PAI-1 in $R M C s$

As shown in figures 3 and 4, Ang II markedly increased PARP-1, FN and PAI-1 mRNA at 12 and $24 \mathrm{~h}$, respectively $(p<0.05)$, compared with control cells. PJ34 effectively inhibited the upregulation of PARP-1, PAI-1 and FN mRNA at 12 and $24 \mathrm{~h}$, respectively $(\mathrm{p}<0.05)$, compared with the cells treated with Ang II alone. Similarly, siRNA duplex targeting PARP-1 significantly inhibited the upregulation of PARP-1, PAI-1 and FN mRNA at 12 and $24 \mathrm{~h}$, respectively $(\mathrm{p}<0.05)$. However, PJ34 alone did not affect basal levels of PARP-1, PAI-1 and FN mRNA. In addition, scrambled siRNA duplex did not affect Ang II-induced upregulation of PARP-1, PAI-1 and FN mRNA in RMCs at 12 and $24 \mathrm{~h}$, respectively.

\section{Effect of PJ34 and siRNA Duplex Targeting PARP-1} on Ang II-Induced Protein Expression of PARP-1,

FN and PAI-1 in RMCs

As shown in figures 5 and 6, Ang II stimulated PARP1, PAI-1 and FN protein expression at 12 and $24 \mathrm{~h}$, respectively ( $p<0.05)$, compared with control cells. PJ34 effec-

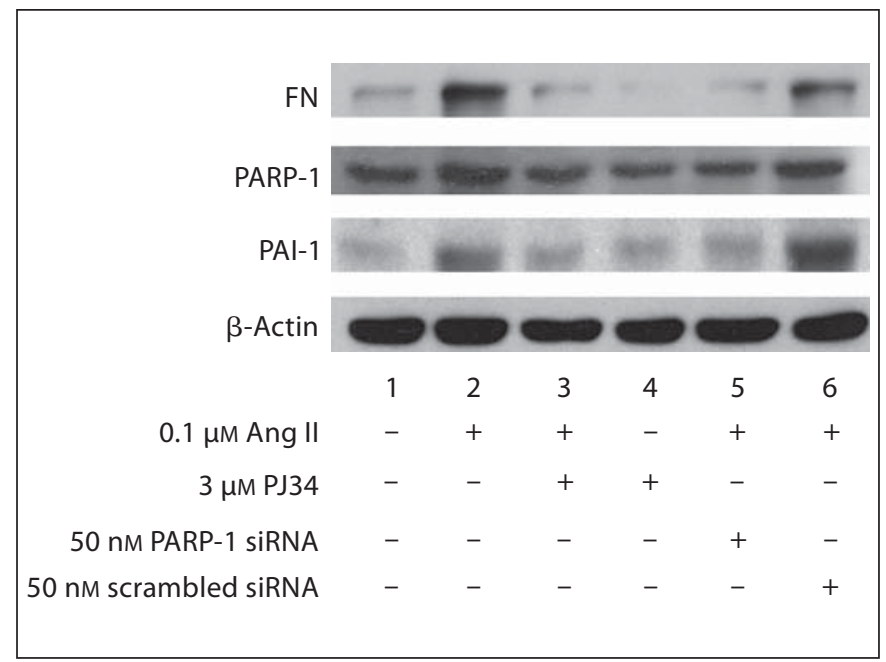

Fig. 6. Effects of PJ34 and siRNA duplexes targeting PARP-1 on Ang II-induced protein expression of PARP-1, PAI-1 and FN in RMCs at $24 \mathrm{~h}$ determined by Western blot. The intensity of the resultant bands are scanned and expressed as a ratio of $\beta$-actin: (1) RMCs treated with vehicle (blank), (2) RMCs treated with Ang II $(0.1 \mu \mathrm{M})$, (3) RMCs pretreated with PJ34 $(3 \mu \mathrm{M})$ followed by Ang II $(0.1 \mu \mathrm{M})$ treatment, (4) RMCs treated with PJ34 (3 $\mu \mathrm{M})$ alone, (5) RMCs pretreated with PARP-1 siRNA (50 nM) followed by Ang II $(0.1 \mu \mathrm{M})$ treatment, and (6) RMCs treated with scrambled siRNA (50 $\mathrm{nM})$ followed by Ang II $(0.1 \mu \mathrm{M})$.

tively inhibited the upregulation of PARP-1, PAI-1 and FN protein expression induced by Ang II, respectively $(\mathrm{p}<$ 0.05), compared with the cells treated with Ang II alone. Similarly, siRNA duplex targeting PARP-1 significantly inhibited the upregulation of PARP-1, PAI-1 and FN expression induced by Ang II $(\mathrm{p}<0.05)$. However, PJ34 alone did not affect basal protein expression of PARP-1, PAI-1 and FN, and scrambled siRNA duplex did not affect Ang II-induced PARP-1, PAI-1 and FN upregulation in RMCs.

\section{Discussion}

Renal mesangial cells play a critical role in glomerulosclerosis. Over the last decade, it has been clear that Ang II regulates the growth (including hyperplasia and hypertrophy) of mesangial cells, and increases synthesis and expression in ECM proteins $[5,11]$. The ECM proteins consist of FN, collagen, laminin, and others [5, 24-26]. However, our understanding of the precise mechanism is unclear and this study focused on the intracellular signaling mechanisms involved in Ang II-induced PAI-1 and FN expression in RMCs. In this study, we have demon- 
strated for the first time that the PARP-1 inhibition decreased Ang II-induced upregulation of PAI-1 and FN expression in cultured RMCs, showing direct cellular effects of PARP-1 inhibitors and knockdown by its siRNA on Ang II-induced fibrotic responses.

PARPs, as poly(ADP-ribosyl)ating enzymes, are involved in many cellular processes, including the control of repair of damaged DNA (especially single-strand breaks) and the control of gene expression/transcription $[16,27]$. Inhibition of PARP activity can lead to protection against many pathophysiological outcomes [16, 27]. PARP-1-deficient mice and PARP inhibitors have been shown to significantly reduce ECM accumulation in various diseases [28-32]. All of these data coincided with our findings. In this study, we found that Ang II stimulation in RMCs led to PARP-1 activation, including upregulation of PARP-1 activity, mRNA and protein. PJ34 is a water-soluble, highly selective competitive inhibitor of PARP activity [33]. Devoid of inherent antioxidant activity, it functions by blocking the NAD+ binding site of PARP competitively $[17,34]$. The enzymatic inhibition effect of PJ34 is much stronger than any other traditional inhibitor of PARP, which is 10,000-fold that of 3-AB [35]. In this study, PJ34 not only inhibited PARP activity, but also inhibited mRNA and protein expression of PARP-1, which is contrary to some studies [36]. However, the mechanism is still unclear. It may be involved in some unknown effects of PJ34 besides its competitive inhibition property. Further studies need to be done to explore the potential mechanism.

Our data estimated that inhibition of PARP-1 by PJ34 or its siRNA effectively attenuates Ang II-induced PAI-1 and FN expression in RMCs. It implied that PARP-1 might be a critical mediator in Ang II-induced ECM accumulation in RMCs. Several studies suggested that inhibition of PARP-1 could attenuate Ang II-induced pathological outcomes. PARP-1-deficient mice were protected from Ang II-induced cardiac hypertrophy. Therefore, PARP-1 is a nuclear mediator of Ang II-mediated cell signaling contributing to cardiac hypertrophy [37]. Ang II in rats and cultured endothelial cells induced PARP activation in a dose-dependent manner. The PARP inhibitors PJ34 or INO-1001 prevented the development of the endothelial dysfunction and restored normal endothelial function [18]. Treatment with Ang II promotes PARP-1 activation in cultured cardiac fibroblasts. Inhibition of PARP-1 by PJ34 or its siRNA oligonucleotide effectively prevented Ang II-induced increase in collagen $I \alpha 1$ and III $\alpha 1$, MMP-9 and TIMP-1 [32].

Since we demonstrated that PARP mediated Ang II-induced FN expression in RMCs, we further sought to un- cover the underlying mechanism. Two main degrading systems are known to be involved, namely matrix metalloproteinases (MMPs) and the plasminogen activation system (PAS) $[9-11,38]$. MMPs are a family of zinc-binding proteolytic enzymes capable of degrading components of the ECM $[39,40]$. The plasminogen/plasmin system was first recognized for its fibrin-degrading activity and is the main efficient fibrinolytic system in vivo. The system consists of tissue-type (t-PA) plasminogen activators (PAs), urokinase-type (u-PA) PAs and their specific inhibitors PAI [38, 41]. PAI-1, a $50-\mathrm{kDa}$ glycoprotein, is the main PAI secreted in vivo and is a potent fast-acting and irreversible inhibitor of t-PA and u-PA. It forms stochiometric complexes with active PAs, which are subsequently endocytosed and degraded. Moreover, PAI-1 is also a component of the ECM, where it seems to bind tightly to the somatomedin B domain of vitronectin [42]. In pathological conditions in vivo, human mesangial cells overexpress PAI-1, and this upregulation may be related to the stimulation by various cytokines or growth factors such as TNF- $\alpha$ [43] and TGF- $\beta$ [44]. In the present study, we have found the molecular mechanisms involved in a beneficial effect that PARP-1 inhibition decreased Ang II-induced upregulation of PAI-1 and FN expression in cultured RMCs. However, there is still no literature that elucidates the relationship between PARP-1 activation and PAI-1 peptides. Whether the inhibition of PAI-1 peptides is responsible for PARP-1-mediated PAI-1 expression needs to be elucidated.

In conclusion, our present data suggest that PARP-1 mediates Ang II-induced PAI-1 and FN expression in RMCs, and thus may represent a potential therapeutic target in the treatment of glomerular disease.

\section{Acknowledgement}

This work was supported by a grant from the National Natural Science Foundation of China (No. 30771012).

References

1 Wang H, Zhang L, Lv J: Prevention of the progression of chronic kidney disease: practice in China. Kidney Int Suppl 2005;94:S63S67.

2 Xie Y, Chen X: Epidemiology, major outcomes, risk factors, prevention and management of chronic kidney disease in China. Am J Nephrol 2008;28:1-7.

-3 Chen W, Wang H, Dong X, Liu Q, Mao H, Tan J, Lin J, Zhou F, Luo N, He H, Johnson RJ, Zhou SF, Yu X: Prevalence and risk factors associated with chronic kidney disease in an adult population from southern China. Nephrol Dial Transplant 2009;24:1205-1212. 
4 Ikizler TA: Epidemiology of vascular disease in renal failure. Blood Purif 2002;20:6-10.

5 Mezzano SA, Ruiz-Ortega M, Egido J: Angiotensin II and renal fibrosis. Hypertension 2001;38:635-638.

-6 Schanstra JP, Neau E, Drogoz P, Arevalo Gomez MA, Lopez Novoa JM, Calise D, Pecher C, Bader M, Girolami JP, Bascands JL: In vivo bradykinin $\mathrm{B} 2$ receptor activation reduces renal fibrosis. J Clin Invest 2002;110: 371-379.

-7 Wynn TA: Cellular and molecular mechanisms of fibrosis. J Pathol 2008;214:199-210.

-8 Douillette A, Bibeau-Poirier A, Gravel SP, Clement JF, Chenard V, Moreau P, Servant MJ: The proinflammatory actions of angiotensin II are dependent on $\mathrm{p} 65$ phosphorylation by the IкB kinase complex. J Biol Chem 2006;281:13275-13284.

-9 Bascands JL, Schanstra JP: Obstructive nephropathy: insights from genetically engineered animals. Kidney Int 2005;68:925937.

10 Ma LJ, Fogo AB: PAI-1 and kidney fibrosis. Front Biosci 2009;14:2028-2041.

-11 Fogo AB: Mesangial matrix modulation and glomerulosclerosis. Exp Nephrol 1999;7: 147-159.

12 Kurogi Y: Mesangial cell proliferation inhibitors for the treatment of proliferative glomerular disease. Med Res Rev 2003;23:1531.

13 Hassa PO, Haenni SS, Elser M, Hottiger MO: Nuclear ADP-ribosylation reactions in mammalian cells: where are we today and where are we going? Microbiol Mol Biol Rev 2006;70:789-829.

- 14 Dawson VL, Dawson TM: Deadly conversations: nuclear-mitochondrial cross-talk. J Bioenerg Biomembr 2004;36:287-294.

$\checkmark 15$ Andrabi SA, Dawson TM, Dawson VL: Mitochondrial and nuclear cross-talk in cell death: parthanatos. Ann N Y Acad Sci 2008; 1147:233-241.

16 Virag L, Szabo C: The therapeutic potential of poly(ADP-ribose) polymerase inhibitors. Pharmacol Rev 2002;54:375-429.

- 17 Du X, Matsumura T, Edelstein D, Rossetti L, Zsengeller Z, Szabo C, Brownlee M: Inhibition of GAPDH activity by poly(ADPribose) polymerase activates three major pathways of hyperglycemic damage in endothelial cells. J Clin Invest 2003:112:10491057.

18 Szabo C, Pacher P, Zsengeller Z, Vaslin A, Komjati K, Benko R, Chen M, Mabley JG, Kollai M: Angiotensin II-mediated endothelial dysfunction: role of poly(ADP-ribose) polymerase activation. Mol Med 2004; 10 : $28-35$.
19 Szabo C, Biser A, Benko R, Bottinger E, Susztak K: Poly(ADP-ribose) polymerase inhibitors ameliorate nephropathy of type 2 diabetic Leprdb/db mice. Diabetes 2006;55: 3004-3012.

20 Shevalye H, Maksimchyk Y, Watcho P, Obrosova IG: Poly(ADP-ribose) polymerase-1 (PARP-1) gene deficiency alleviates diabetic kidney disease. Biochim Biophys Acta 2010; 1802:1020-1027.

21 Vaschetto R, Kuiper JW, Chiang SR, Haitsma JJ, Juco JW, Uhlig S, Plotz FB, Della Corte F, Zhang H, Slutsky AS: Inhibition of poly(adenosine diphosphate-ribose) polymerase attenuates ventilator-induced lung injury. Anesthesiology. 2008;108:261-268.

22 Rhyu DY, Yang Y, Ha H, Lee GT, Song JS, Uh ST, Lee HB: Role of reactive oxygen species in TGF- $\beta_{1}$-induced mitogen-activated protein kinase activation and epithelial-mesenchymal transition in renal tubular epithelial cells. J Am Soc Nephrol 2005;16:667-675.

23 Pfaffl MW: A new mathematical model for relative quantification in real-time RT-PCR. Nucleic Acids Res 2001;29:e45.

24 Mooney A, Jackson K, Bacon R, Streuli C Edwards G, Bassuk J, Savill J: Type IV collagen and laminin regulate glomerular mesangial cell susceptibility to apoptosis via $\beta_{1}$ integrin-mediated survival signals. Am J Pathol 1999;155:599-606.

25 Kim S, Iwao H: Molecular and cellular mechanisms of angiotensin II-mediated cardiovascular and renal diseases. Pharmacol Rev 2000;52:11-34.

26 Miner JH: Renal basement membrane components. Kidney Int 1999;56:2016-2024.

27 Graziani G, Szabo C: Clinical perspectives of PARP inhibitors. Pharmacol Res 2005;52: 109-118.

28 Xu B, Chiu J, Feng B, Chen S, Chakrabarti S: PARP activation and the alteration of vasoactive factors and extracellular matrix protein in retina and kidney in diabetes. Diabetes Metab Res Rev 2008:24:404-412.

29 Chiu J, Farhangkhoee H, Xu BY, Chen S, George B, Chakrabarti S: PARP mediates structural alterations in diabetic cardiomyopathy. J Mol Cell Cardiol 2008;45:385-393.

- 30 Nicolescu AC, Holt A, Kandasamy AD, Pacher P, Schulz R: Inhibition of matrix metalloproteinase-2 by PARP inhibitors. Biochem Biophys Res Commun 2009;387:646650.

31 Li M, Threadgill MD, Wang Y, Cai L, Lin X: Poly(ADP-ribose) polymerase inhibition down-regulates expression of metastasis-related genes in CT26 colon carcinoma cells. Pathobiology 2009;76:108-116.

- 32 Huang D, Wang Y, Yang C, Liao Y, Huang K: Angiotensin II promotes poly(ADP-ribosyl) ation of c-Jun/c-Fos in cardiac fibroblasts. J Mol Cell Cardiol 2009;46:25-32.
33 Casey PJ, Black JH, Szabo C, Frosch M, Albadawi $\mathrm{H}$, Chen $\mathrm{M}$, Cambria RP, Watkins MT: Poly(adenosine diphosphate ribose) polymerase inhibition modulates spinal cord dysfunction after thoracoabdominal aortic ischemia-reperfusion. J Vasc Surg 2005;41:99-107.

-34 Fiorillo C, Ponziani V, Giannini L, Cecchi C, Celli A, Nassi N, Lanzilao L, Caporale R, Nassi P: Protective effects of the PARP-1 inhibitor PJ34 in hypoxic-reoxygenated cardiomyoblasts. Cell Mol Life Sci 2006;63: 3061-3071.

- 35 Besson VC, Zsengeller Z, Plotkine M, Szabo $C$, Marchand-Verrecchia C: Beneficial effects of PJ34 and INO-1001, two novel watersoluble poly(ADP-ribose) polymerase inhibitors, on the consequences of traumatic brain injury in rat. Brain Res 2005;1041:149-156.

36 Goebel DJ, Winkler BS: Blockade of PARP activity attenuates poly(ADP-ribosyl)ation but offers only partial neuroprotection against NMDA-induced cell death in the rat retina. J Neurochem 2006;98:1732-1745.

-37 Pillai JB, Gupta M, Rajamohan SB, Lang R, Raman J, Gupta MP: Poly(ADP-ribose) polymerase-1-deficient mice are protected from angiotensin II-induced cardiac hypertrophy. Am J Physiol Heart Circ Physiol 2006; 291:H1545-H1553.

- 38 Rerolle JP, Hertig A, Nguyen G, Sraer JD, Rondeau EP: Plasminogen activator inhibitor type 1 is a potential target in renal fibrogenesis. Kidney Int 2000;58:1841-1850.

-39 Lelongt B, Ronco P: Role of matrix metalloproteinases in kidney development and glomerulopathy: lessons from transgenic mice. Nephrol Dial Transplant 2002;17(suppl 9): 28-31.

40 Marti HP: The role of matrix metalloproteinases in the activation of mesangial cells. Transpl Immunol 2002;9:97-100.

$41 \mathrm{Ha} \mathrm{H}$, Lee HB: Reactive oxygen species and matrix remodeling in diabetic kidney. J Am Soc Nephrol 2003;14:S246-S249.

42 Knudsen BS, Harpel PC, Nachman RL: Plasminogen activator inhibitor is associated with the extracellular matrix of cultured bovine smooth muscle cells. J Clin Invest 1987; 80:1082-1089.

43 Kishida M, Urakaze M, Takata M, Nobata Y, Yamamoto N, Temaru R, Sato A, Yamazaki K, Nakamura N, Kobayashi M: PGE1 inhibits the expression of PAI-1 mRNA induced by TNF- $\alpha$ in human mesangial cells. Exp Clin Endocrinol Diabetes 2005;113:365-371.

44 Yang C, Glass WF 2nd: Expression of $\alpha$-actinin-1 in human glomerular mesangial cells in vivo and in vitro. Exp Biol Med (Maywood) 2008;233:689-693. 